\title{
Prizmatik Derin Çekme İşlemlerinde Farklı Malzemelere Uygulanan Tavlama İşleminin Biçimlendirilebilirliğe Etkisi
}

\author{
Kamil DELIKKANLI ${ }^{1}$, Mert ENGÍN² ${ }^{2}$ Osman TUNÇ ${ }^{3}$ \\ ${ }^{1}$ Süleyman Demirel Üniversitesi, Mühendislik Fakültesi, Makine Mühendisliği Bölümü, Isparta, Türkiye \\ 2,3Süleyman Demirel Üniversitesi, Fen Bilimleri Enstitüsü, Yüksek Lisans Öğrencisi, Isparta, Türkiye
}

(Alınıș / Received: 15.06.2021, Kabul / Accepted: 18.07.2021)

\section{Araştırma Makalesi}

Anahtar Kelimeler

Prizmatik derin çekme,

HRP,

DKP,

CuZn37
Özet: Derin çekme işlemi sac levhaların şekillendirilmesinde kullanılan etkin yöntemlerden biridir. Günümüz ihtiyaçları arttıkça üretime çeşitlilik kazandırılması amacıyla farklı malzemelerin işlenmesi ve imalata kazandırılması kaçınılmaz olmuştur. Bu makalede derin çekmenin bir çeşidi olan prizmatik derin çekme işlemi kullanılarak farklı malzemeler olan; sıcak dökülmüş (HRP), soğuk haddelenmiş (DKP) ve pirinç alaşımının bu prosesle işlenebilirlik kabiliyetleri deneysel olarak araştırılmıștır. Malzemelerden alınan numunelere uygulanan farklı tavlama sıcaklıkları ve sürelerine bağlı olarak malzemelerin işlenebilirlikleri yapılan deneylerle gözlemlenmiştir. Gözlemlenen verilerden elde edilen grafikler yorumlanarak tavlama parametrelerinin yapılan farklı deneyler üzerindeki etkisi belirlenmeye çalışmıştır. Bu etkilerin belirlenmesi ile prizmatik derin çekme ile imalatın verimliliğini artırmak amaçlanmıștır. Yapılan tavlama işlemlerinin, farklı malzemelerin farklı özellikleri üzerinde \%5 ila \%200 arasında bir değişime sebep olabileceği saptanmıştır.

\section{The Annealing Effect of Different Materials on Formability in Prismatic Deep Drawing Processes}

\section{Keywords}

Prismatic deep drawing,

HRP,

DKP,

CuZn37

\begin{abstract}
Deep drawing is one of the effective methods used in shaping sheet metal. Nowadays, as the needs increase, it has become inevitable to process different materials and add them to production in order to gain variety in production. In this article, the machinability capabilities of different materials HRP (hot rolled), DKP (cold rolled) and brass alloys were experimentally investigated by using the prismatic deep drawing process, which is a type of deep drawing. Depending on different annealing temperatures and times applied on samples taken from materials the machinability of the materials has been observed with the experiments. Interpreting the graphs obtained from the observed data, the effects of annealing parameters on different experiments were tried to be determined. With the determination of these effects, it is aimed to increase the productivity of the production with prismatic deep drawing. It has been determined that the annealing processes can cause a change between $5 \%$ and $200 \%$ on the different properties of different materials.
\end{abstract}

\section{Giriş}

Tavlama işlemi, imalat sektöründe kullanılan birçok malzemenin farklı endüstrilerde kullanılmasını sağlar. Ham malzemelerin mekanik özellikleri, tavlama işlemine tabi tutulduktan sonra tavlama parametrelerine bağlı olarak değişime uğrar [3]. Bu değișim ile malzemelerin farklı endüstrilerde kullanılmasının ve farklı ürünler imal edilmesinin önü açilır.

İmal edilecek malzemenin farklı geometrilerde olması veya farklı mekanik özelliklere sahip olması istenebilir. Aynı zamanda malzemenin mekanik özelliklerinin imalat yöntemine uygun olması da göz 
önünde bulundurulan bir diğer unsurdur. Bu şartlar, tavlama işlemini imalat sektöründe zorunlu kılar.

Tavlama ana hatları ile bir malzemenin belirli bir sıcaklığa belirli bir süre maruz bırakılmasına verilen isimdir. $\mathrm{Bu}$ sürede yüksek sıcaklığa ulaşan malzemenin tane yapısı ve tane sinırları, tavlama parametrelerine bağlı olarak değișime uğrayıp malzemenin mekanik özelliklerini etkileyebilir [6]. Farklı sıcaklık ve süreler farklı etkiler yaratabilir [15]. Mevcut değişim malzemenin kontrollü olarak soğutulması ile kalıcı hale gelir ve malzemenin mekanik özellikleri bu işlem sonucunda farklılaşır [7].

Derin çekme işleminde kullanılan malzemelerin de bu imalat yöntemine uygun özelliklere kavuşturulmaları için tavlama işleminden geçirilmeleri gerekebilir [4].

Derin çekme işlemi, yassı formdaki bir malzemenin Şekil 1'deki gibi bir kalıp içerisine bir zımba yardımı ile çekilerek üç boyutlu (3B) geometriler imal edilmesine verilen addır.[8] Bu imalat yöntemi birçok endüstride yoğunlukla kullanılmaktadır. Otomotiv endüstrisinde otomobillerin kaporta aksamı, beyaz eşya endüstrisinde bazı makinelerin parçaları gibi imalatlar buna örnektir [13].

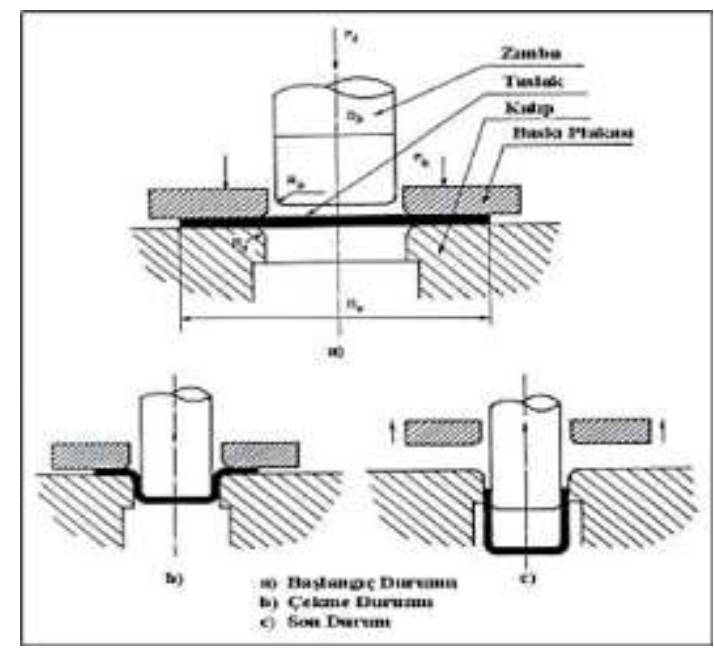

Şekil 1. Derin çekme kalıbı ve derin çekme prensibi [1]

Derin çekme işlemi ile imal edilen parçaların geometrik biçimi, işlem sırasında istenmeyen deformasyonlara sebep olabilir [11]. Bu deformasyonların önlenebilmesi ve istenilen nitelikte bir imalatın yapılabilmesi için kullanılan malzemeler tavlama işleminden geçirilebilir. Bu tavlama işlemi neticesinde istenmeyen deformasyonların gerçekleşmesinin önüne geçilebilir ve imalatın istenilen kalitede gerçekleşmesi sağlanabilir [10].

\section{Materyal ve Metot}

\subsection{Malzeme özelliklerinin belirlenmesi}

Çalışmada 1,5 mm kalınlığındaki HRP, DKP ve Pirinç malzemelerin tavlama işlemi sonucunda değişim gösteren mekanik özelliklerinin, bu malzemelerin derin çekilebilirlik özelliklerine etkisinin araştırılması amaçlanmıştır.

Kullanılan malzemelerin kimyasal bileșim özellikleri Tablo 1'de görülmektedir.

Tablo 1. Malzemelerin kimyasal özellikleri

\begin{tabular}{|l|l|l|l|l|}
\hline Malzeme & \%C & \%Mn & \%P & \%S \\
\hline $\begin{array}{l}\text { HRP } \\
\text { (S235JR) }\end{array}$ & 0,17 & 1,40 & 0,035 & 0,035 \\
\hline DKP (6112) & 0,12 & 0,60 & 0,045 & 0,045 \\
\hline
\end{tabular}

\begin{tabular}{|l|l|l|l|l|l|l|}
\hline Malzeme & \%Cu & \%Fe & \%Ni & \%Pb & \%Sn & \%Al \\
\hline $\begin{array}{l}\text { Pirinç } \\
\text { (CuZn37) }\end{array}$ & 64 & 0,10 & 0,30 & 0,10 & 0,10 & 0,05 \\
\hline
\end{tabular}

\subsection{Deney numunelerinin hazırlanması}

Derin çekme işlemi ve uygulanacak diğer deneyler için tavlama işlemlerinden geçirilecek malzemeler, her biri 80 × 80 × 1,5mm ebatlarında olacak biçimde, lazer kesim cihazı yardımı ile kesilerek numuneler elde edilmiştir.

\subsection{Malzemeler üzerinde yapılan tavlama işlemi}

Hazırlanan deney numuneleri Tablo 2'de görülen şartlardaki tavlama işlemlerinden geçirilmiştir.

Tablo 2. Tavlama parametreleri

\begin{tabular}{|l|l|l|l|}
\hline & HRP & DKP & Pirinç \\
\hline Ham & - & - & - \\
\hline $\mathbf{3 0 0}{ }^{\circ} \mathbf{C}$ & $30^{\prime}$ & $30^{\prime}$ & $30^{\prime}$ \\
\hline $\mathbf{4 5 0}^{\circ} \mathbf{C}$ & $60^{\prime}$ & $60^{\prime}$ & $60^{\prime}$ \\
\hline $\mathbf{6 0 0}^{\circ} \mathbf{C}$ & $90^{\prime}$ & $90^{\prime}$ & $90^{\prime}$ \\
\hline
\end{tabular}

\subsection{Malzemeler üzerinde yapılacak prizmatik derin çekme işlemi}

Aynı şartlar altında hazırlanan derin çekme deneyi numuneleri, prizmatik derin çekme kalıbı kullanılarak Şekil 2'de görülen 41 x 41 x 19,5mm ebatlarında üç boyutlu (3B) bir forma kavuşturulmak amaçlanmıştır.

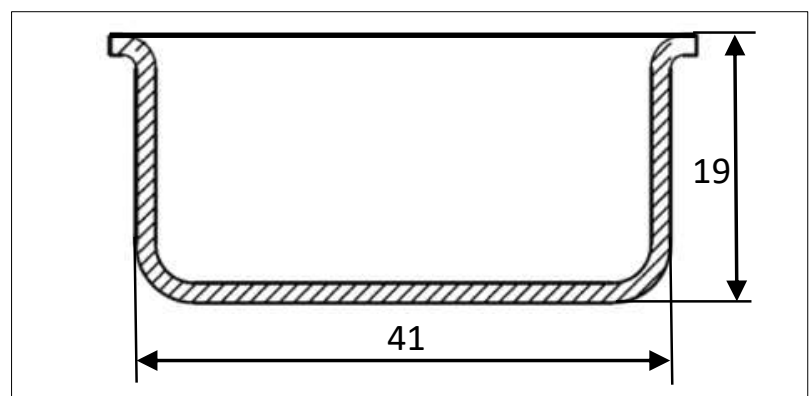

Şekil 2. Prizmatik derin çekme işlemi ile oluşturulmak istenen geometri

Derin çekme işlemleri sonucunda farklı tavlama parametrelerine sahip numuneler üzerinde farklı deformasyonlar gözlemlenebilir [12]. 
Yapılan çalışmalarda derin çekme işlemi ile imalatı yapılan kaplarda meydana gelen kulaklanma ve buruşma değerlerinin belirlenmesi amaçlanmıştır. Diğer deformasyonlar göz ardı edilmiştir ve çalışmada bunlara değinilmeyecektir.

Derin çekme işlemi sonrası malzemelerde meydana gelen kulaklanma ve buruşma değerlerinin ölçümü Şekil 3'teki gibi yapılmıştır.

Kulaklanma miktarı belirlenirken imal edilen kabın kenarlarındaki maksimum çıkıntı - derinlik miktarı ölçülmüştür.

Buruşma miktarı belirlenirken maksimum kulaklanmanın olduğu bölgedeki kesit kalınlığı değeri ölçülmüştür.

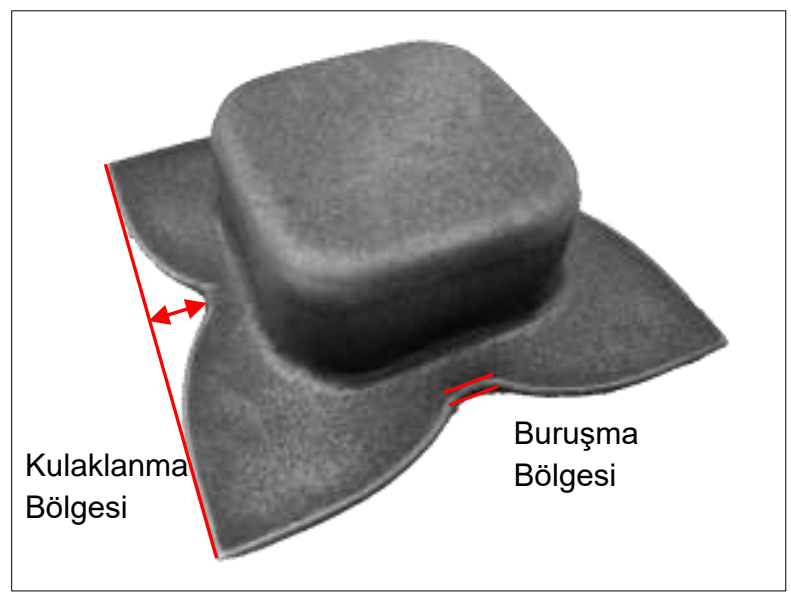

Şekil 3. Derin çekme işlemi sonucunda oluşan kulaklanma ve burușma bölgeleri

Her bir numune üzerinde yapılan ölçümler sonucunda Tablo 3 düzenlenmiştir.

Tablo 3. Derin çekme işlemi sonrası ölçülen değerler

\begin{tabular}{|c|c|c|c|c|c|}
\hline Malzeme & $\begin{array}{c}\text { Tav } \\
\text { Parametresi }\end{array}$ & Durum & $\begin{array}{l}\text { Strok } \\
(\mathrm{mm})\end{array}$ & $\begin{array}{c}\text { Kulaklanma } \\
(\mathrm{mm})\end{array}$ & $\begin{array}{c}\text { Buruşma } \\
(\mathrm{mm})\end{array}$ \\
\hline \multirow{4}{*}{ HRP } & Ham & Kırılmadı & 19,5 & 7,3 & 0,5 \\
\hline & $300^{\circ} \mathrm{C} 90^{\prime}$ & Kırıldı & 17 & 5,33 & 0,4 \\
\hline & $450^{\circ} \mathrm{C} 90^{\prime}$ & Kırılmadı & 19,5 & 7,61 & 0,5 \\
\hline & $600^{\circ} \mathrm{C} 90^{\prime}$ & Kırılmadı & 19,5 & 7,96 & 0,65 \\
\hline \multirow{4}{*}{ DKP } & Ham & Kırıldı & 11 & 2,13 & 0,15 \\
\hline & $300^{\circ} \mathrm{C} 90^{\prime}$ & Kırıldı & 10 & 2,33 & 0,1 \\
\hline & $450^{\circ} \mathrm{C} 90^{\prime}$ & Kırıldı & 14,5 & 3,38 & 0,3 \\
\hline & $600^{\circ} \mathrm{C} 90^{\prime}$ & Kırıldı & 16,5 & 4,4 & 0,4 \\
\hline \multirow{4}{*}{ Pirinç } & Ham & Kırılmadı & 19,5 & 7 & 0,3 \\
\hline & $300^{\circ} \mathrm{C} 90^{\prime}$ & Kırıldı & 14 & 2,3 & 0,4 \\
\hline & $450^{\circ} \mathrm{C} 90^{\prime}$ & Kırıldı & 13,5 & 3,9 & 0,2 \\
\hline & $600^{\circ} \mathrm{C} 90^{\prime}$ & Kırıldı & 19,5 & 7,9 & 0,5 \\
\hline
\end{tabular}

\subsection{Malzemeler üzerinde yapılacak testler}

Malzemeler çeşitli testlerden geçirilmiştir. Tavlanmış ve ham malzemeler üzerinde yapılan yüzey sertliği, yüzey pürüzlülüğü ve Erichsen çökertme deneyi sonuçları, yapılan derin çekme deneyi sonuçları ile karşılaştırılarak tavlama ile değişen mekanik özelliklerin derin çekmeye etkisi belirlenmeye çalışılmıştır.

Derin çekme işlemi sonucunda elde edilen numuneler göz önüne alınarak farklı sıcaklıklarda 90'ar dakika tavlanan numunelerin 30 ve 60'ar dakika tavlanan numunelere kıyasla daha fazla farklılaşmaya uğradığı saptanmıştır. $\mathrm{Bu}$ nedenle malzemeler üzerinde yapilan deneylerde $300^{\circ} \mathrm{C}, \quad 450^{\circ} \mathrm{C}$ ve $600^{\circ} \mathrm{C}$ sicaklıklarda 90'ar dakika tavlama işlemine tabi tutulmuş numuneler kullanılmıştır.

\subsubsection{Yüzey sertliği}

Malzemelerin yüzey sertlik değerinin derin çekme işlemine olan olası etkisinin araştırılması için ham ve tavlanmış numuneler üzerinde micro vickers yüzey sertliği deneyleri yapılmıştır.

Micro vickers yöntemi elmas uçlu, tepe açısı $136^{\circ}$ olan kare piramit formunda bir zımba ucunun sabit bir kuvvet ile malzeme yüzeyine bastırılması ile yapılmaktadır [14]. Bu kuvvet neticesinde zımba ucu malzeme yüzeyinde Şekil 4'te görüldüğü gibi bir iz bırakır. Bu iz optik mikroskop yardımı ile ölçülerek malzemenin yüzey sertlik değeri belirlenmeye çalışılır.

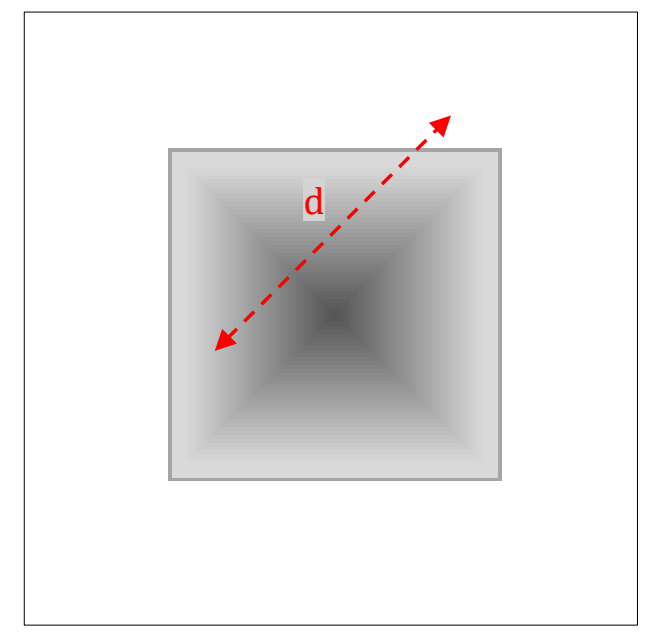

Şekil 4. Zımba ucunun malzeme üzerinde bıraktığı iz

Ölçülen iz köșegenleri değerleri (d) ve uygulanan yük (kg) değerleri vickers sertlik değeri formülünde yerine yazılarak sertlik değeri hesaplanır.

Vickers sertlik değeri formülü şu şeklindedir [5]:

$$
V S D=1,8544 \cdot \frac{F}{d^{2}}
$$

Deneylerde her bir malzemenin farklı üçer bölgesindeki sertlik değerleri ölçülerek ortalama değerleri hesaplanmıştır ve Tablo 4 bu değerlere göre hazırlanmıștır. 
Tablo 4. Malzemelerin micro vickers sertlik değerleri

\begin{tabular}{|l|l|l|l|l|}
\hline & Ham & $\mathbf{3 0 0}^{\circ} \mathbf{C} \mathbf{9 0}^{\prime}$ & $\mathbf{4 5 0}^{\circ} \mathbf{C} \mathbf{9 0}^{\prime}$ & $\mathbf{6 0 0}^{\circ} \mathbf{C} \mathbf{9 0}^{\prime}$ \\
\hline HRP & 150,267 & 151,733 & 141,267 & 134,733 \\
\hline DKP & 148,266 & 158,6 & 156,7 & 154,766 \\
\hline Pirinç & 120,4 & 120,9 & 105,5 & 83,3 \\
\hline
\end{tabular}

\subsubsection{Erichsen çökertme deneyi}

Malzemelerin farklı tav parametrelerinde derin çekme işlemi sırasında oluşacak sonuçları, malzemeye uygulanan kuvvet paralelinde maksimum çökme miktarının hesaplanması amaçlanarak Erichsen çökertme deneyi yapılmıştır. Bu deney malzemenin derin çekme yeteneğini belirlemek için dikkat edilen bir standarttır. Ulaşılan veriler ile malzemenin derin çekme kabiliyeti tespit edilmiştir.

Erichsen çökertme deneyi temelde yassı malzemelerin derin çekilebilirlik kabiliyetlerini ölçmeye yarayan bir deneydir [9]. Deneyde yassı malzeme Şekil 5'te görüldügü üzere tıpkı bir derin çekme kalıbındaki gibi alt tabla ve üst tabla arasında sıkıştırılarak yüzeyine küresel bir zımba ucu ile bastırılır. Bastırma kuvveti ile malzeme çökmeye başlayarak üç boyutlu (3B) bir form almaya başlar. Deney malzeme yırtılasıya kadar devam eder ve malzemenin çatlamasıyla sonlanır. Deney sonunda çatlamanın gerçekleştiği maksimum kuvvet $(\mathrm{kN})$ ve maksimum çökme miktarı (mm) kayıt altına alınır.

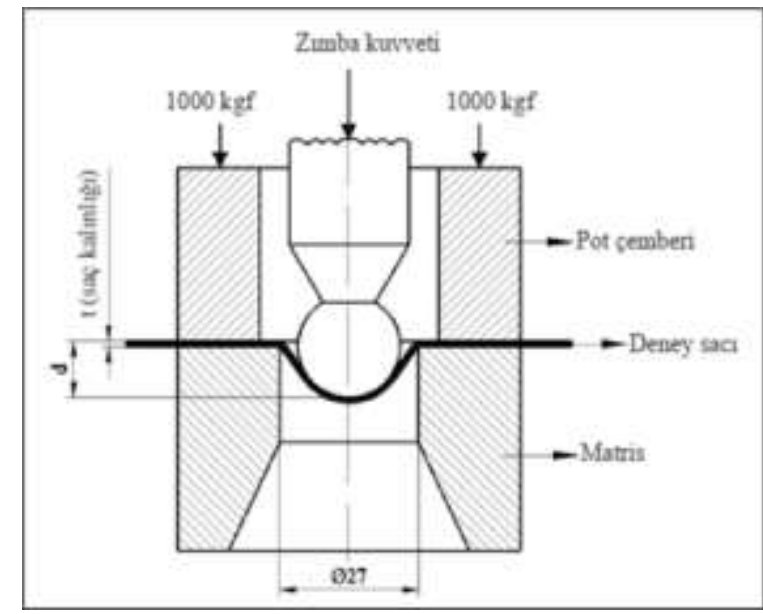

Şekil 5. Erichsen deney düzeneği [2]

Yapılan deney sonucunda malzemelerin tavlama parametresi - baskı kuvvet ve tavlama parametresi çökertme derinliği değerleri elde edilmiş olup bu değerler Tablo 5'te görülmektedir.
Tablo 5. Malzemelerin Erichsen çökertme deneyi sonuçları

\begin{tabular}{|c|c|c|c|}
\hline Malzeme & $\begin{array}{c}\text { Tav } \\
\text { Parametresi }\end{array}$ & $\begin{array}{c}\text { Derinlik } \\
(\mathrm{mm})\end{array}$ & Kuvvet (kN) \\
\hline \multirow{4}{*}{ HRP } & Ham & 13,5 & 25,2 \\
\hline & $300^{\circ} \mathrm{C} 90^{\prime}$ & 13,4 & 25,3 \\
\hline & $450^{\circ} \mathrm{C} 90^{\prime}$ & 13,4 & 25,7 \\
\hline & $600^{\circ} \mathrm{C} 90^{\prime}$ & 13,5 & 25,8 \\
\hline \multirow{4}{*}{ DKP } & Ham & 14,3 & 23,4 \\
\hline & $300^{\circ} \mathrm{C} 90^{\prime}$ & 13,2 & 23 \\
\hline & $450^{\circ} \mathrm{C} 90^{\prime}$ & 13,2 & 23,1 \\
\hline & $600^{\circ} \mathrm{C} 90^{\prime}$ & 13,4 & 23,7 \\
\hline \multirow{4}{*}{ Pirinç } & Ham & 14,5 & 25,1 \\
\hline & $300^{\circ} \mathrm{C} 90^{\prime}$ & 14,3 & 24,7 \\
\hline & $450^{\circ} \mathrm{C} 90^{\prime}$ & 15,3 & 24 \\
\hline & $600^{\circ} \mathrm{C} 90^{\prime}$ & 18,7 & 24,2 \\
\hline
\end{tabular}

\subsubsection{Derin çekme işlemi sonrası yüzey pürüzlülüğü ölçümü}

Derin çekme işleminden geçirilen ham ve tavlanmış malzemelerin yan yüzeylerinde oluşan düzensiz yapıların gözlemlenmesi amacıyla malzemeler üzerinde derin çekme doğrultusuna dik yönde yüzey pürüzlülük ölçümleri gerçekleştirilmiştir. Ölçümler sonucunda $\mathrm{R}_{\max }$ (Maksimum pürüzlülük derinliği) değerleri belirlenmiștir.

Derin çekme imalat yöntemi ile üretilen malzemelerin yüzey kaliteleri çoğu zaman büyük önem arz eder. İmalat sonrası kaplama - boyama gibi işlemlerin istenilen düzeyde yapılabilmesi için pürüzlülük değerinin uygun değerde olması şarttır.

Her bir numuneden elde edilen yüzey pürüzlülük ölçümleri ile Tablo 6 hazırlanmıștır.

Tablo 6. Yüzey pürüzlülük ölçümleri

\begin{tabular}{|l|l|l|l|l|}
\hline & Ham & $\mathbf{3 0 0}^{\circ} \mathbf{C} \mathbf{9 0}^{\prime}$ & $\mathbf{4 5 0}^{\circ} \mathbf{C} \mathbf{9 0}^{\prime}$ & $\mathbf{6 0 0}^{\circ} \mathbf{C} \mathbf{9 0}^{\prime}$ \\
\hline HRP & $\begin{array}{l}2,55 \\
\mu \mathrm{m}\end{array}$ & $1,48 \mu \mathrm{m}$ & $1,27 \mu \mathrm{m}$ & $1,32 \mu \mathrm{m}$ \\
\hline DKP & $\begin{array}{l}1,42 \\
\mu \mathrm{m}\end{array}$ & $0,94 \mu \mathrm{m}$ & $1,45 \mu \mathrm{m}$ & $1,36 \mu \mathrm{m}$ \\
\hline Pirinç & $\begin{array}{l}0,62 \\
\mu \mathrm{m}\end{array}$ & $0,64 \mu \mathrm{m}$ & $0,57 \mu \mathrm{m}$ & $1,74 \mu \mathrm{m}$ \\
\hline
\end{tabular}

\section{Bulgular}

Yapılan derin çekme işlemi ve testlerden elde edilen sonuçlar ışığında tabloların birer grafiği çizilmiştir.

Grafiklerde; üçgen işaretçiye sahip veriler, derin çekme işlemi sonucunda kırılmış numuneleri temsil etmektedir.

Derin çekme işlemi sonrası elde edilen malzemelerdeki kulaklanma ve buruşma değerleri Şekil 6 ve Şekil 7 'deki grafiklerde görülmektedir. 
Farklı şartlardaki tavlama işlemlerinin derin çekme işlemi ile imal edilen kaplar üzerindeki etkisi bu şekilde belirlenmeye çalışılmıştır.

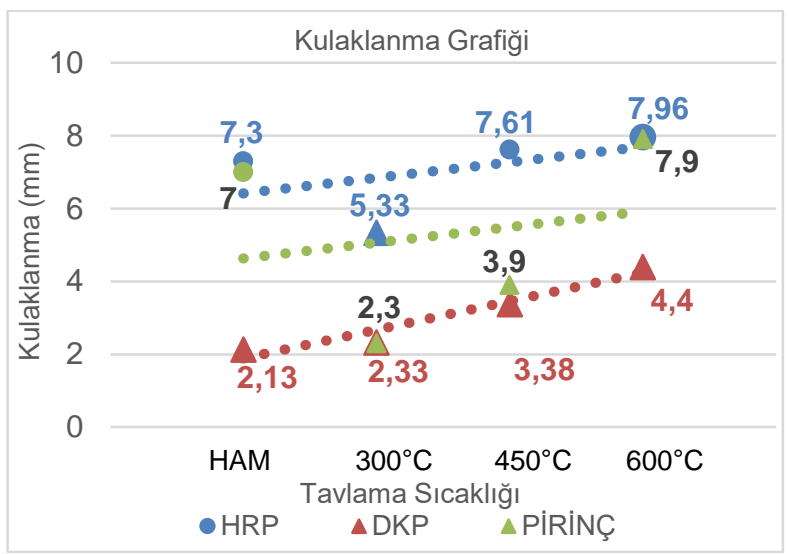

Şekil 6. Tavlama sıcaklığı - kulaklanma grafiği

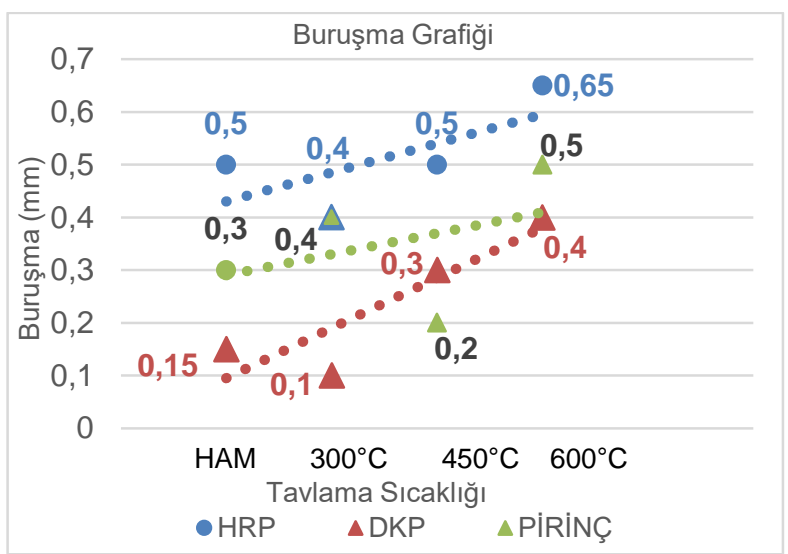

Şekil 7. Tavlama sıcaklığı - buruşma grafiği

Şekil 6'daki grafikte görüldüğü üzere malzemelere etkiyen tavlama sıcaklığı arttıkça imal edilen kapta meydana gelen kulaklanma artma eğilimine girmektedir.

Şekil 7'de derin çekme işlemi ile imal edilen kaplarda meydana gelen buruşma değeri görülmektedir. Daha yüksek tavlama sıcaklığının beraberinde daha yüksek buruşma değerini de meydana getirdiği gözlemlenmektedir.

Derin çekme işlemine tabi tutulacak ham ve tavlanmış malzemeler üzerinde yapılmış yüzey sertliği ölçümü değerleri ile elde edilen grafik Şekil 8`de verilmiştir.

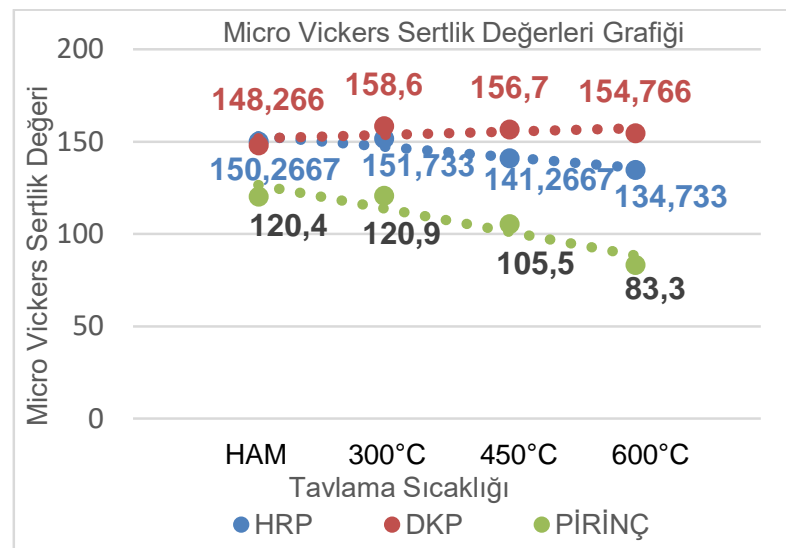

Şekil 8. Tavlama sıcaklı̆̆ - micro vickers sertlik değeri grafiği

Şekil 8'deki grafikte malzemelere uygulanan tavlama sıcaklığındaki değişimin yüzey sertliği değeri üzerindeki etkisi gözlemlenmiştir. Grafik incelendiğinde HRP ve pirinç malzemenin yüzey sertliği değerinin tavlamanın etkisi ile azalma eğiliminde olduğu gözlemlenmektedir. Öte yandan DKP malzemenin yüzey sertliği ham haline oranla yaklaşık $\% 5$ ile $\% 6$ oranında sertleşmiştir.

Derin çekme işlemi uygulanacak ham ve tavlanmış numuneler üzerinde yapılan Erichsen çökertme deneyi sonuçlarından elde edilen grafikler Şekil 9 ve Şekil 10'da görülmektedir.

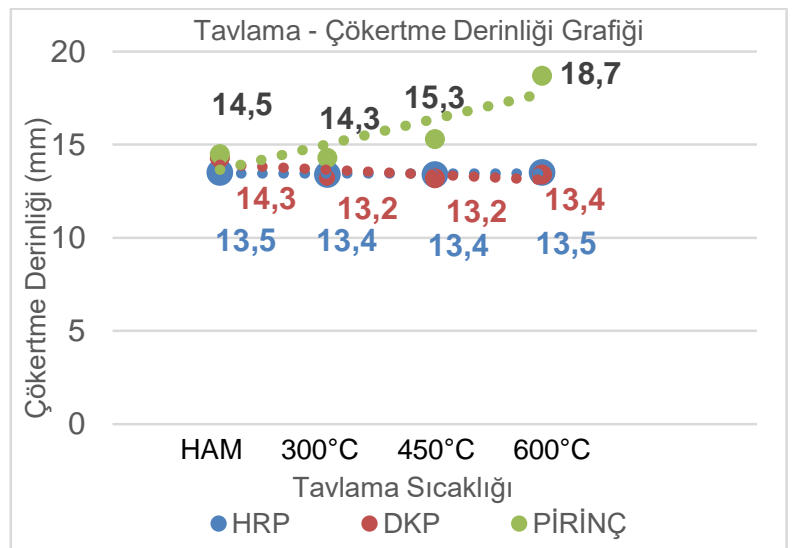

Şekil 9. Tavlama sıcaklığı - çökertme derinliği grafiği

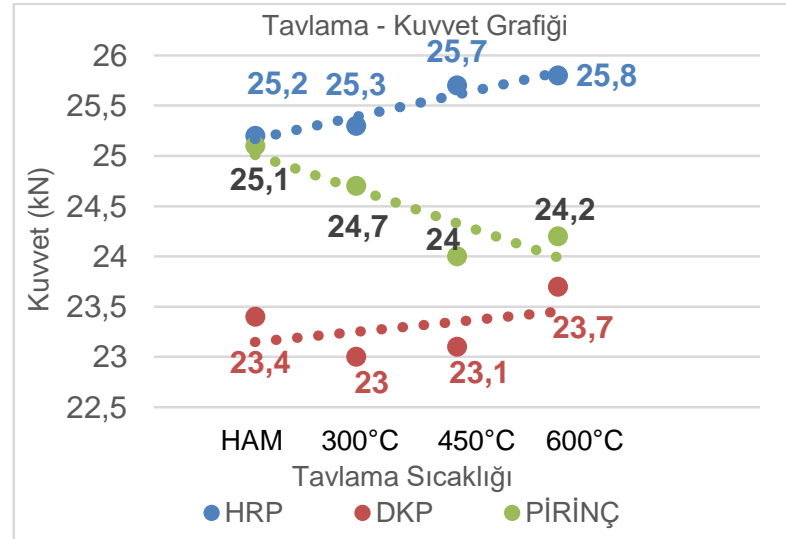

Şekil 10. Tavlama sıcaklığı - kuvvet grafiği 
Şekil 9'da görülen grafikte tavlama sıcaklık parametresinin Erichsen deneyindeki zımba ucu derinliği üzerindeki etkisi gözlemlenmektedir. HRP ve DKP malzemelerde belirgin bir değișim gözlemlenemezken pirinç malzeme üzerinde meydana gelen derinlik sıcaklığın artması ile yaklaşık \%30 artmıştır.

Şekil 10'da verilen tavlama parametresi ile Erichsen deneyi kuvveti arasındaki bağıntıyı gösteren grafikte tavlama sıcaklığının maksimum zımba kuvveti üzerinde büyük ölçüde düzenli bir değișim gösteremediği saptanmıştır. Gözlenen değişim deneyin tolerans değerlerinin altında kalacak değerde küçük düzeyde gözlemlenmiștir.

Derin çekme işlemi sonucunda elde edilen malzemelerin yan yüzeylerinde derin çekme yönüne dik biçimde yapılan yüzey pürüzlülük ölçümlerinden elde edilen grafik Şekil 11 'de görülmektedir.

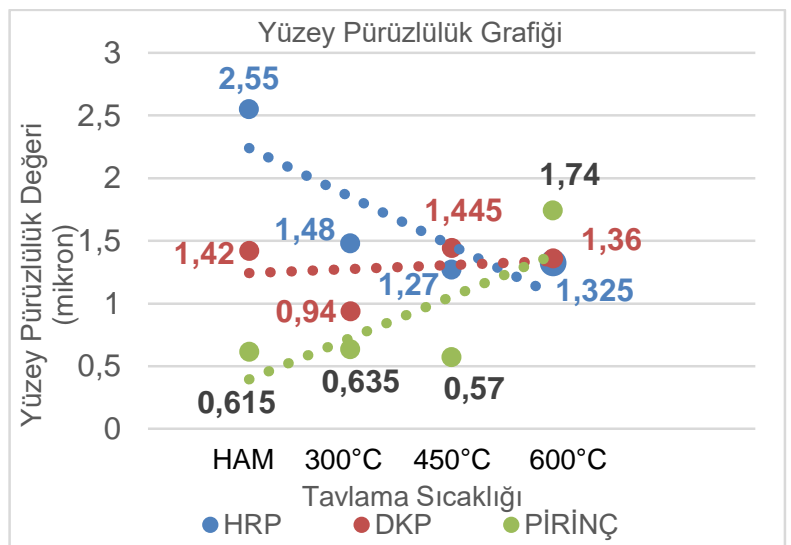

Şekil 11. Tavlama sıcaklığı - yüzey pürüzlülük değeri grafiği

Şekil 11'de derin çekme işlemi ile imalatı yapılmış kaplarda meydana gelen yüzey düzensizliklerinin tavlama parametresi ile değişimi gözlemlenmiştir. Tavlama sıcaklığının artması ile HRP malzemede meydana gelen pürüzlülük değeri azalma eğilimine girmiştir. DKP malzemede düzenli bir değişim gözlemlenemezken pirinç malzemede $600^{\circ} \mathrm{C}$ sıcaklığında yapılan tavlamanın ölçülen pürüzlülüğü yaklaşık \%200 arttırdığı gözlemlenmiştir.

Bulgularda görüldüğü üzere tavlama işlemi yapılmış farklı malzemelere yapılan çeşitli deneyler ile malzemelerin belirlenen özellikleri, \%5 ila \%200 arasında bir farklılaşma göstermektedir.

\section{Tartışma ve Sonuç}

Yapılan çalışmalar sonucunda tavlama işleminin malzemelere olan etkisi belirlenmeye çalışılmıştır. Bu etkinin derin çekme üzerindeki yansıması şu şekilde gözlemlenmiştir:

Tavlama işleminin optimum etkiyi gösterebilmesi için tavlama süresi 90 dakika olarak belirlenmiștir.
- Tavlama sıcaklığı üzerinde yapılan değişiklilerde; artan tavlama sıcaklığının derin çekme ile imalatı yapılan kaplarda oluşan kulaklanma değerini artırdığı, kulaklanma değerinin artmasına paralel olarak kulaklanma bölgesindeki buruşma değerinin de belirli oranda arttığı saptanmıştır.

- Artan tavlama sıcaklığının derin çekme stroğunu artırmasının, kulaklanma ve buruşma değerinin de aynı oranda artması ile derin çekme yeteneği ve kulaklanma, buruşma arasındaki ilișki açılklanabilir. DKP malzemedeki strok artışı ile kulaklanma ve buruşmadaki artış bu şekilde açılklanabilir.

- Artan tavlama sıcaklı̆̆ının aynı zamanda HRP ve pirinç malzemenin yüzey sertliklerini belirli oranda azalttığ öte yandan DKP malzemenin ise yüzey sertliğini belirli oranda arttırdığı belirlenmiştir. HRP ve pirinç malzemelerin yüzey sertliklerinin azalması ile kulaklanma ve buruşma değerlerindeki artış bu bağıntı ile açıklanabilir.

- Malzemelere yapilan Erichsen deneylerinde ise HRP ve DKP malzemelerin derin çekilebilirlik kabiliyetlerine, tavlama işleminin makro düzeyde etkisinin az ölçüde olduğu belirlenmiştir. Pirinç malzemede ise tavlama sıcaklığının artması ile derin çekme stroğu değerinin arttığı saptanmıştır.

- Derin çekme işlemi ile imal edilmiş kapların yan yüzeylerinde, derin çekme doğrultusuna dik yönde yapılan pürüzlülük ölçümlerinde HRP malzemenin artan tavlama sıcaklı̆̆ değeri ile daha pürüzsüz bir yapıya sahip olduğu, pirinç malzemede ise yüksek sıcaklık değerinin pirincin ergime sıcaklığına yaklaşmasından dolayı pürüzlülük değerinin arttı̆̆ı saptanmıştır. DKP malzemede ise düzenli bir değişim gözlemlenememiştir.

Belirlenen bu değerler ışığında;

1. HRP malzemenin tavlama sıcaklığının artması ile yüksek kulaklanma ve buruşma değerine ulaştığı ve buna karşın yüzey pürüzlülüğünün yüzey sertliği değeri ile birlikte azaldığı belirlenmiștir. Ferrit bölge içerisinde kalacak şekilde yapılan bu tavlama işlemi HRP malzemenin derin çekilebilirlik yeteneğini ise düşük ölçüde etkilemektedir.

2. DKP malzemenin tavlama sıcaklığının artması ile yüksek kulaklanma ve buruşma değerine ulaştı̆̆ı belirlenmiştir. Yüzey pürüzlülüğü değerinin tavlama sıcaklığı parametresine bağıntısı belirlenememiş olup yüzey sertliği 
değeri ise artma eğilime girmektedir. Ferrit bölge içerisinde kalacak şekilde yapılan bu tavlama işlemi DKP malzemenin derin çekilebilirlik yeteneğini ise düşük ölçüde etkilemektedir.

3. Pirinç malzemenin tavlama sıcaklı̆̆ının artması ile yüksek kulaklanma ve buruşma değerine ulaştığı belirlenmiştir. Yüzey sertliği değerinin ise büyük oranda azaldığı saptanmış olup yüzey pürüzlülüğü değeri ergime noktasına yaklașılması ile artmıștır. Tavlama sıcaklığının artması ile malzemenin derin çekilebilirlik yeteneğinin de arttığı tespit edilmiştir.

4. Farklı malzemeler kullanılarak yapılan bu çalışmada, malzemelerin tavlama sıcaklığına verdiği tepki belirlenmeye çalışılmıştır. Her bir malzeme ile yapılacak olan derin çekme ile imalatta, farklı tavlama parametrelerinin istenen imalata uygun biçimde seçilmesi gerekmektedir.

5. Yapılan deneylerde yüksek tavlama sıcaklığının kullanılan malzemelerden bağımsız olarak kulaklanma ve burușmayı arttırdığı tespit edilirken diğer sonuçların malzemeye bağımlı olarak değiştiği tespit edilmiștir.

\section{Kaynakça}

[1] Çetin, H. 2005. Alüminyum Alaşımı Hafif Metal Levhaların Prizmatik Derin Çekmede Biçimlendirilebilirlik Özelliklerinin Araştırılması. SDÜ, FBE, Yüksek Lisans Tezi, 163s, Isparta.

[2] Dengiz, C.G. 2014. Desenli Çelik Sacların Şekil Alma Kabiliyetlerinin Araştırılması. Mühendis ve Makine Dergisi, cilt 55, sayı 650, s. 47-55.

[3] Erdem, G. 1999. Sürekli Tavlama Prosesi ile Tavlanacak Derin Çekme Çelik Kalitelerin Sıcak Haddeleme Proses Parametrelerinin Optimizasyonu. İTÜ, FBE, Doktora Tezi, 125s, İstanbul.

[4] Gürün, H. 2008. Derin Çekme Kalıplarındaki Parametrelerin Deneysel Olarak İncelenmesi ve Bulanık Mantık ile Tahmini. Gazi Üniversitesi, Fen Bilimleri Enstitüsü, Doktora Tezi, 154 s, Ankara.

[5] Kayalı, E.S. 1990. Metalik Malzemelerin Mekanik Deneyleri, 168s, İstanbul.

[6] Kayalı, E.S., Ensari, C. 2000. Metallere Plastik Şekil Verme İlke ve Uygulamaları, 420s, İstanbul.

[7] Özkan, S. 2013. Alaşımlı Bakır Levhaların Derin Çekme Prosesinde Gerilme Analizi. Gazi Üniversitesi, Fen Bilimleri Enstitüsü, YL Tezi, 130s, Ankara.
[8] Öztürk, T. 1984. Çelik Sacların Biçimlendirme Özellikleri. Mühendis ve Makina Dergisi, cilt 25, sayı 292, s. 12-17.

[9] Singh, M., Choubey, A.K., Sasikumar, C. 2017. Formability Analysis of Aluminium Alloy by Erichsen Cupping Test Method, Materialstoday Proceedings, cilt 4, sayı 2, s.805-810.

[10] Sümer, H. 2018. Derin Çekme Yöntemi. 30.09.2020. https://argevetasarım.com/derincekme-yöntemi

[11] Şener, B. 2012. Otomotiv Sektöründe Kullanılan Derin Çekme Saclarının Şekillendirilebilirliğinin Analizi. İTÜ, FBE, Yüksek Lisans Tezi, 140s, İstanbul.

[12] Takalkar, A.S., Chinnapandi, L.B.M. 2019. Deep Drawing Process At The Elevated Temperature: A Critical Review And Future Research Directions, CIRP Journal of Manufacturing Science and Technology, sayı 27, s. 56-67.

[13] Taşdemir, V. 2013. Derin Çekme İşlemi Üzerine Kalıp Geometrisinin Etkisinin Sonlu Elemanlar Analizi, KSU Mühendislik Bilimleri Dergisi,16(1), s. $43-47$.

[14] Zamfirova, G., Dimitrova, A. 2000. Some methodological contributions to the Vickers microhardness technique, Polymer Testing, cilt 19 , sayı 5 , s. 533-542.

[15] Zheng, K., Zhu, L., Lin, J., Dean, T.A., Li, N. 2019. An Experimental İnvestigation of The Drawability Of AA6082 Sheet Under Different Elevated Temperature Forming Processes. Journal of Materials Processing Tech, sayı 273. 